\title{
A VILÁGJÁRVÁNY HATÁSA A GLOBÁLIS LOGISZTIKAI FOLYAMATOKRA
}

\author{
Nagy Gábor \\ tudományos segédmunkatárs, Miskolci Egyetem, Logisztikai Intézet \\ 3515 Miskolc-Egyetemváros, e-mail: altnagy@uni-miskolc.hu \\ Bányainé Tóth Ágota \\ egyetemi docens, Miskolci Egyetem, Logisztikai Intézet \\ 3515 Miskolc-Egyetemváros, e-mail: altagota@uni-miskolc.hu

\section{Illés Béla} \\ egyetemi tanár, Miskolci Egyetem, Logisztikai Intézet \\ 3515 Miskolc-Egyetemváros, e-mail: altilles@uni-miskolc.hu

\section{Varga Attila Károly} \\ egyetemi docens, Miskolci Egyetem, Automatizálási és Infokommunikációs Intézet \\ 3515 Miskolc-Egyetemváros, e-mail:varga.attila@uni-miskolc.hu
}

\begin{abstract}
Absztrakt
A COVID-19 világjárvány emlékeztette a társadalmat arra, hogy a természeti katasztrófák mellett a járványok is részét képezik múltunknak, jelenünknek és jövőnknek. Még ha nem is tudjuk megakadályozni a veszélyes vírusok megjelenését, fel kell készülnünk arra, hogy csillapitsuk a társadalomra gyakorolt hatásukat. Egyértelmüen kijelenthetö, hogy a COVID-19 járvány a súlyos élettani hatása mellett jelentős gazdasági károkat okozott világszerte. A különbözö iparágak globális ellátási láncainak jelentős nehézségekkel kell megbirkózniuk. Nemcsak a gazdaságra van hatással a vírus; az egész társadalom érintett, ami drámai változásokhoz vezetett a vállalkozások és a fogyasztók viselkedésében. A világot behálózó ellátási láncoknak, amelyek az elmúlt évtizedekben magas szintü stabilitást és rugalmasságot mutattak, számos zavaró tényezövel kel most szembenézniük. A világjárvány a lánc teljes egészét hátrányosan érintette mind a gyártási, mind a logisztikai folyamatok vonatkozásában, valamint a kereslet jelentös elmozdulásával. A világjárvány rámutatott arra, hogy az ellátási láncok alkalmazkodóképességének fokozása érdekében három kulcsfontosságú területet kell szem elött tartani: kockázat és rugalmasság, globális átláthatóság, valamint gyors reagálás és döntés. Megállapitható, hogy a járvány okozta változások hatására a globális ellátási láncok rövidebbek és átláthatóbbak lesznek az olyan megújult stratégiák révén, mint a digitalizáció melynek eszközei a DSN épitöelemei.
\end{abstract}

Kulcsszavak: Covid-19, globális ellátási lánc, digitalizáció, DSN-digitális ellátási hálózat

\begin{abstract}
The COVID-19 pandemic reminded society that, in addition to natural disasters, epidemics are also part of our past, present and future. Even if we cannot prevent the emergence of dangerous viruses, we must be prepared to mitigate their impact on society. It is clear that the COVID-19 epidemic, in addition to its severe physiological effects, has caused significant economic damage worldwide. Global supply
\end{abstract}


chains in different industries face significant challenges. Not only is the economy affected by the virus; society as a whole is affected, leading to dramatic changes in the behavior of businesses and consumers. The global supply chains that have shown a high level of stability and resilience in recent decades now face a number of disruptive factors. The pandemic adversely affected the entire chain in terms of both manufacturing and logistics processes, as well as a significant shift in demand. The pandemic highlighted the need to focus on three key areas to increase the resilience of supply chains: risk and flexibility, global transparency, and rapid response and decision-making. It can be concluded that the changes caused by the epidemic will make global supply chains shorter and more transparent through renewed strategies such as digitization, the tools of which are the building blocks of the DSN.

Keywords: Covid-19, global supply chain, digitisation, DSN-digital supply network

\section{Bevezetés}

Az Egészségügyi Világszervezet (WHO) adataiból kiindulva a COVID-19 járvány 2019 decemberi felbukkanása óta napjainkra már több mint 220 országban van jelen, 2020 év végéig több mint 82 millió megerősített COVID-19 esetet regisztráltak, amelyből 1,8 millió halállal végződött [1].

1. táblázat Az áruforgalom volumene és a reál-GDP a 2015-2021 intervallumban [3]

\begin{tabular}{|c|c|c|c|c|c|c|c|}
\hline & 2015 & 2016 & 2017 & 2018 & 2019 & 2020 & 2021 \\
\hline $\begin{array}{c}\text { A világkereskedelem } \\
\text { volumene(export és import } \\
\text { átlaga) }\end{array}$ & 2,3 & 1,4 & 4,7 & 2,9 & $-0,1$ & $-9,2$ & 7,2 \\
\hline Export & & & & & & & \\
\hline Észak-Amerika & 2,6 & 0,7 & 3,4 & 3,8 & 1 & $-14,7$ & 10,7 \\
\hline Dél-és Közép Amerika & 0,6 & 1,3 & 2,9 & 0,1 & $-2,2$ & $-7,7$ & 5,4 \\
\hline Európa & 2,9 & 1,1 & 3,7 & 2 & 0,1 & $-11,7$ & 8,2 \\
\hline Ázsia & 1,3 & 2,3 & 6,7 & 3,7 & 0,9 & $-4,5$ & 5,7 \\
\hline $\begin{array}{c}\text { Más régiók( Afrika, Közel-Kelet } \\
\text { és a Független Államok } \\
\text { Közössége (FÁK) }\end{array}$ & 1,8 & 3,5 & 0,7 & 0,7 & $-2,9$ & $-9,5$ & 6,1 \\
\hline Import & & & & & & & $\mathrm{I}$ \\
\hline Észak-Amerika & 5,2 & 0,3 & 4,4 & 5,2 & $-0,4$ & $-8,7$ & 6,7 \\
\hline Dél-és Közép Amerika & $-7,6$ & -9 & 4,3 & 5,3 & $-2,1$ & $-13,5$ & 6,5 \\
\hline Európa & 3,6 & 3 & 3 & 1,5 & 0,5 & $-10,3$ & 8,7 \\
\hline Ázsia & 2,1 & 2,2 & 8,4 & 4,9 & $-0,6$ & $-4,4$ & 6,2 \\
\hline $\begin{array}{c}\text { Más régiók( Afrika, Közel-Kelet } \\
\text { és a Független Államok } \\
\text { Közössége (FÁK) }\end{array}$ & $-3,9$ & $-4,5$ & 3,4 & 0,3 & 1,5 & -16 & 5,6 \\
\hline Reál GDP piaci árfolyamon & $\overline{2,8}$ & $\overline{2,4}$ & 3,1 & 2,8 & 2,2 & $-4,8$ & 4,9 \\
\hline Észak-Amerika & 2,8 & 1,7 & 2,4 & 2,8 & 2,1 & $-4,4$ & 3,9 \\
\hline Dél-és Közép Amerika & $-0,8$ & -2 & 0,8 & 0,6 & $-0,2$ & $-7,5$ & 3,8 \\
\hline Európa & 2,4 & 2,1 & 2,8 & 2,1 & 1,5 & $-7,3$ & 5,2 \\
\hline Ázsia & 4,3 & 4,2 & 4,8 & 4,1 & 3,9 & $-2,4$ & 5,9 \\
\hline $\begin{array}{c}\text { Más régiók( Afrika, Közel-Kelet } \\
\text { és a Független Államok } \\
\text { Közössége (FÁK) }\end{array}$ & 1,5 & 2,4 & 1,9 & 2,1 & 1,4 & $-5,5$ & 3,5 \\
\hline
\end{tabular}


A 2020-as év a világ számára a prevencióról szólt, ezért minden érintett ország korlátozásokat vezetett be a vírus terjedésének megfékezésére. A világ országai egyetértettek abban, hogy az elsődleges cél a járvány kapcsán, hogy a vírus terjedésével növekvő betegszámot próbálják csökkenteni, megóvva ezzel a társadalmat a káros élettani hatásoktól. A járvány másik velejárója viszont, hogy a bevezetett korlátozások súlyos gazdasági hatást váltottak ki a világ összes országában. A Világkereskedelmi Szervezet (WTO) elörejelzése szerint a globális kereskedelem volumene 32\%-ról 13\% -ra esett vissza [2]. A WTO adatbázisában található adatokat az 1. táblázat szemelteti, amelyben a főbb gazdasági régiók becsült globális kereskedelmi volumenét láthatjuk, ami a számok tükrében valóban aggodalomra adhat okot a gazdaság aspektusából.

A pandémia megfékezése céljából számos elővigyázatossági intézkedést vezettek be a kormányok, mint például az utazási korlátozásokat, a gyárak és üzletek átmeneti leállítását vagy bezárását, valamint az állampolgárok kötelező izolációját. Emiatt sok vállalkozás bezárásra kényszerült, ami a kereskedelem példátlan zavaraihoz vezetett a legtöbb ipari szektorban. A helyzetet tovább súlyosbította a logisztikai rendszerek ellenőrzésének szigorítása is. Emiatt a tervezett átfutási idők megváltoztak, késések mutatkoztak a folyamatokban. Bizonyos termékek iránt robbanásszerüén megnőtt a vevő igény, így sok esetben készlethiány is jelentkezett. Egyelőre nem lehet pontosan megbecsülni a járvány végét, ezért fontos, hogy a vállalatok felkészüljenek a gyors helyreállításra és a jövőben várható váratlan zavarok csillapítására.

\section{A járvány hatása a logisztikai folyamatokra}

A történelem során nem a COVID-19 az első olyan járvány, ami ilyen hírtelen és súlyosan érintette a civilizációt és ezzel párhuzamosan a gazdaságot. Előrejelzések szerint 10-50 évente jelennek meg olyan járványok, amelynek kiterjedése globális méretủ. Az elmúlt évtizedekben azonban nem volt olyan mértékü járvány, ami ekkora gazdasági „,pusztítást” okozott volna. Az elmúlt években, évtizedekben pusztító vírusok, természeti katasztrófák időbeni mértéke nem volt olyan elnyúló, mint a Covid-19 járványé. A 1. ábrában olyan paraméterek, jellemzők lettek összegyüjtve, ami magyarázatot ad a jelenlegi világjárvány kontrasztjára a korábbiakkal szemben.

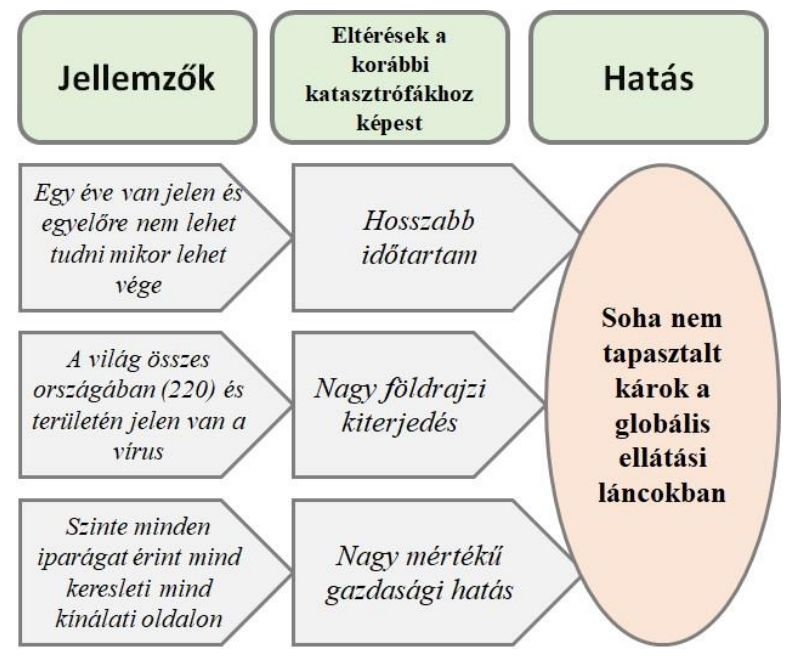

1. ábra A Covid-19 járvány jellemzöi [saját szerkesztés [7] alapján] 
Az áruk mozgatásában, tárolásában és áramlásában részt vevő logisztikai cégeket közvetlenül érintette a COVID-19 járvány. Az értékláncok szerves részeként, mind a nemzetközi határokon belül, mind azokon túl, a logisztikai cégek elősegítik a kereskedelmet, és segítik a vállalkozásokat abban, hogy termékeiket az ügyfelekhez juttassák. Az ágazatokhoz tartozó ellátási láncoknak a járványból adódó zavarai tehát hatással lehetnek a vállalatok versenyképességére, a gazdasági növekedésre és a munkahelyteremtésre. A járvány rávilágított arra is, hogyan függenek egymástól a láncban elhelyezkedő partnerek, mivel az ellátási lánc felső szintjein lévő szereplőket súlyosan érinti a lánc hierarchiában alacsonyabban lévő szereplők kereslet ingadozása [4]. Ez az ismert ostorcsapás-effektus romboló hatással van a felsőbb szintü szereplőkre, főleg a kis- és középvállalkozásokra. Az ostorcsapás hatást az előrejelzés pontatlansága okozza a végfelhasználói keresleti ponton, és jelentős ellátási lánc zavart eredményez [5]. Ilyen esetben szembesülnek a vállalatok a gyengeségeikkel, ilyen például a láthatóság hiánya a lánc teljes hosszában.

\section{Zavarok az ellátási lánc folyamatokban}

A globalizált piacon a logisztikai szolgáltató vállalatok különféle szolgáltatások nyújtásával kötik össze a vállalatokat a piacokkal, mint multimodális szállítás, szállítmányozás, raktározás és készletgazdálkodás [6]. A kiemelkedő gazdasági szektorokhoz tartozó vezető vállalatok a világ számtalan területén müködö beszállítók alkatrészeit használják. Elmondható, hogy a mai globális ellátási láncok nagyobb rugalmasságot és hatékonyságot igényelnek az áruk áramlásában az országok között és azokon belül is. A fogyasztói igények irracionalitása átformálta az eddigi piaci tendenciákat, ami mind a keresleti és kínálati oldalt deformálta. A 2. ábrán látható, hogy a kiemelkedő gazdasági szektorokat miként érinti a világjárvány, a zavarok minden szektorban bekövetkeztek ellátási és keresleti oldalon egyaránt. Általános értelemben a termékek két kategóriába sorolhatók: funkcionális termékek és innovatív termékek.

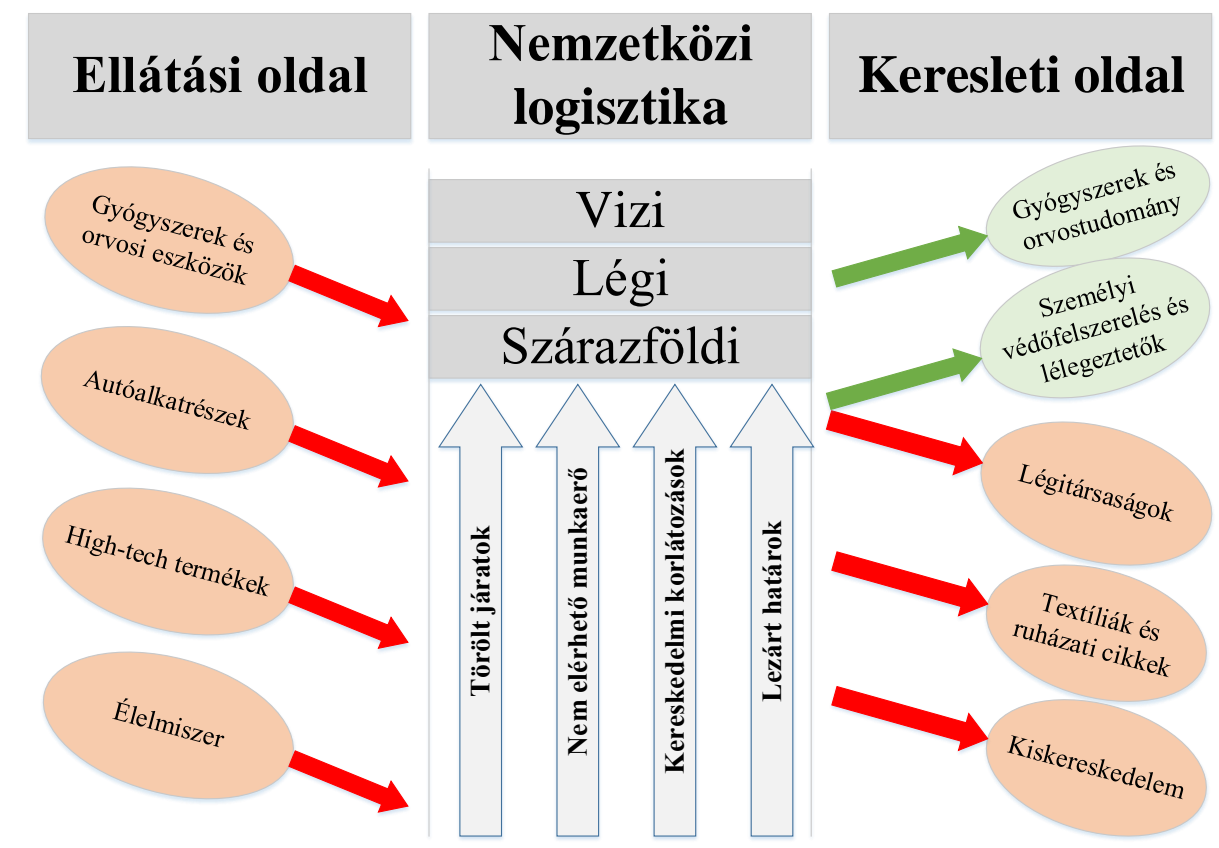

2. ábra A Covid-19 eredményezte hatások a globális ellátási láncokra [saját szerkesztés [7] alapján] 
A funkcionális termékek stabil keresletet és kínálatot mutatnak viszontagságoktól mentes időszakban. Néhány termék, mint például a maszk, a funkcionális termékből innovatív termékké alakult a bizonytalan kereslet és kínálat miatt. A világjárvány idején az ellátási láncok legfontosabb jellemzője a fogyasztók felé történő gyors reagálás és a magas nyereség realizálása.

A vírus által érintett országokban bekövetkező leállások, az emberi erőforrások hiánya, az alapanyagok és a fogyóeszközök korlátozott rendelkezésre állásához vezetett szinte minden ágazatban. A fogyasztók részéről azonban nőttek a COVID-19 megelözésével kapcsolatos eszközök utáni igények. Nagy igény mutatkozott a maszkok iránt, viszont az elektronikai termékek iránti kereslet csökkent, ami a piac egyensúlyának felborulásához vezetett. A vízi, légi és szárazföldi útvonalak nemzetközi logisztikája késéseket, halasztásokat, törléseket és akadályokat tapasztalt a nagyszabású utazási korlátozások és a határok lezárása miatt [8]. Nemzetközi logisztikára nehezedő terhek a járvány alatt megnövekedtek ezzel a globális piacok időben való kiszolgálását. A globális logisztikai szektorban jelentkező szignifikáns válságok oka a munkaerőhiány és a kereskedelmi légiforgalom leállása, illetve a szigorú export- és importkorlátozás. A globális ellátási láncok minden szakaszában hiányzik a megfelelő számú munkaerő, amit karanténkorlátozások, illetve fertőzések eredményeznek. A helyzetet tovább súlyosbítja, hogy az ellátási láncok a létfontosságú feladataikat a karantén, az utazási korlátozások és egyes üzemek ideiglenes leállítása miatt nem tudták ellátni. A kereskedelmi repülés leállítása szerte a világon erősen korlátozta a légi teherkapacitásokat, ami megnehezítette a létfontosságú kellékek, például az orvosi felszerelések mozgatását. Becslések szerint évente több mint 6,2 billió dollár értékủ árut szállítanak légi úton, amely szállítási mód a világkereskedelem értékének több mint $35 \%$-át teszi ki $[9,10]$. A szállítmányozó vállalatok és a kormányok a pandémia alatt a megelőzést és kezelést szolgáló áruk szállításához légi szállítmányozókhoz fordulnak, ami a légi fuvardíjak emelkedését idézte elő, illetve egyes fuvarozók késéseket tapasztalnak a repülőterek fokozott torlódásával. A globális logisztikai folyamatokat tovább sújtja az egyes országok szigorú export- és importkorlátozása, valamint a határok lezárása. Az országok közötti logisztikában jelentős zavarok alakultak ki. A teherautó-soförök hiánya, mint munkaerőhiány itt is jelentős. A vasúti szolgáltatások iránti kereslet nőtt a magasabb légi áruszállítási díjak, az üres hajózás és a teherautók hosszabb tranzitideje miatt.

\section{Enyhítési tervek szoros időbeli korlátok alatt}

A globális ellátási lánc egy többszintủ rendszer, számos láthatatlan, alacsonyabb szintủ beszállítóval, akik nagyon fontosak az ellátási rendszer egészét tekintve. A járvány során bebizonyosodott, hogy csak nagyon kevés integrátor szerepet betöltő vállalatnak sikerült nyomon követnie beszállítóit a II. vagy annál magasabb szinteken. Az ilyen méretekkel rendelkező hálózatok csökkentik a globális ellátási láncok átláthatóságát, ezáltal a váratlan problémákra való lassú reagáláshoz vezetnek [11]. Az ellátási lánc átláthatósága úgy definiálható, hogy az integrátor vállalatoknak tisztában kell lenniük azzal is, hogy mi történik az ellátási láncban az őket megelőző szakaszokban és ezt az információt nem csak az ellátási láncon belül kell kommunikálniuk, hanem a fogyasztók felé is, akik számára ez az információ egyre fontosabbá vált napjainkra [12]. Az ellátási láncban kulcsszerepet betöltő vállalatnál felmerülő zavarok káros következményeket okoznak a globális ellátási lánc egészére. A járvány ideje alatt ez a paraméter felértékelődött mivel nemcsak a láncban érintett vállalatoknak fontos az információ a partnereik müködéséről, hanem a fogyasztónak is a termékek időbeli rendelkezésre állása miatt. A járvány kitörésének gócpontjának számító Vuhan régióból több millió külföldi vállalatnak van egy vagy több II. szintủ beszállítója. Sok esetben ezek olyan kizárólagos beszállítók, akik helyett szinte lehetetlen alternatívát találni. A helyzetet tovább nehezíti az a tény, hogy a gyártó vállalatok napjainkban a lean 
filozófiával törekedtek a hatékonyság növelésére, elsősorban olyan technikák alkalmazásával, mint a just-in-time. Ennek lényege, hogy nem halmoznak fel nagy biztonsági készletszintet, így az ilyen válságos helyzetben kiszolgáltatottak a piaci igényekkel szemben. A vállalatok számára a legsürgetőbb cél az, hogy gyorsan helyreállítsák saját kapacitásukat, valamint az ellátási lánc partnereik kapacitásait. A COVID-19 járvány alatt az ellátási lánc központi vállalatának legfontosabb feladata, hogy üzleti partnereit támogassa. Az integráló szereplőnek gyártania vagy megvásárolnia kell az egyéni védőeszközöket, és segítenie kell az ellátási lánc partnereit a védekező intézkedések végrehajtásában, ezáltal biztosítva beszállítóik gyártásának folyamatosságát. Ezt a stratégiát néhány cég azért követi, hogy megvédje alkalmazottjait, beszállítóit és vásárlóit a védőeszközök hiányának következményeitől. Egyes vezető vállalatok saját erőforrásaik allokálásával a saját gyártás mellett döntenek a védőeszközök előállítása terén, amit a prevenció megfelelő kialakításáig tartanak fennt.

\section{Láthatóság és reakcióképesség kialakítása az értékláncokban}

A láthatóság és a zavarokra adott gyors és hatékony válasz az ellátási lánc rugalmassági mutatói között a legtöbbet vitatott $[13,14]$. A COVID-19 hatásainak enyhítésére érdekében az elsődleges cél a láthatóság megteremtése és a reakcióhoz szükséges feltételek biztosítása (3. ábra).

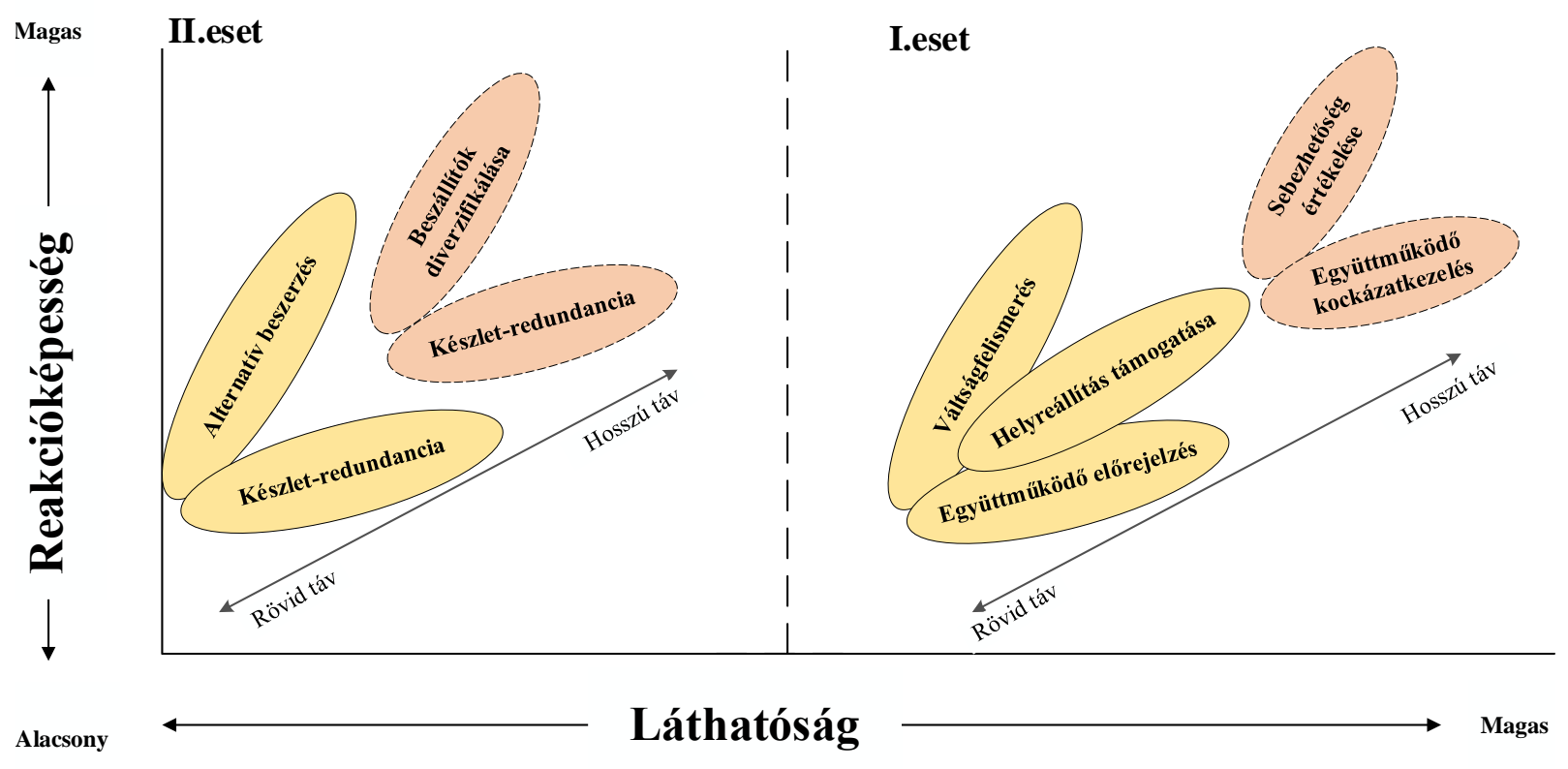

3. ábra Javaslatok a láthatóság és a reakcióképesség fokozására a zavarok enyhitése érdekében [saját szerkesztés [7] alapján]

\subsection{Láthatóságnövelés zavarok esetén}

A vírusoktól és más természeti katasztrófáktól mentes időkben is kiemelkedően fontos tényező a láthatóság fogalma az ellátási láncok müködésében. Egy globális értéklánc felépítése behálózza az egész világot, számtalan gazdasági szereplöt összekapcsolva így fontos a megbízható anyagáramhoz tartozó információ áramlás is. A láthatóság mint fogalom úgy értelmezhető, hogy lehetőséget biztosít az alapanyagfélkésztermék-késztermék nyomon követesére a folyamat teljes egészében. Egyszerü meghatározás 
ellenére ez nem valami könnyen elérhető. A ,jól látható” ellátási lánc jellemzője az a képesség, hogy egy pillanat alatt megállapítja az ellátási lánc összes elemének általános állapotát, valamint a keresési képességét, hogy további részleteket kapjon az aktuális állapotról. Az ellátási lánc bonyolultsága az ellátási lánc láthatósága szempontjából fő kérdés. A vírus alátámasztotta annak tényét, hogy napjainkban a láthatóság mint olyan még nem teljesen kiforrott és bevezetett az ellátási láncok müködésében. Napjaink globális ellátási láncainak csak nagyon kevés százaléka bír teljes láthatósággal. Viszont a láthatóságnövelés elérése a hatékonyság és az agilitás elérése szempontjából alapvető fontosságú.

A rövid távon alkalmazható javaslatokat a veszteségek enyhítésének érdekében a 3. ábra I. esete szemlélteti. A váltságfelismerés azt jelenti, hogy a központi vállalatnak minden alacsonyabb szintü beszállítóját meg kell vizsgálnia a lezárásokkal éríntett területeken. A jelenlegi helyzet által leginkább érintett beszállítók ismerete jelentősen lerövidítheti az enyhítési intézkedések bevezetéséhez szükséges válaszidőt. Az együttmüködő előrejelzés az ügyfelekkel való együttes kereslet-előrejelzést. Segítségével elkerülhető az ostorcsapás hatás, a gyártás- és erőforrás tervezés kiszámíthatóbbá válik. Az adott piacot ellátó termékportfólióból meg kell határozni a fogyasztói igények által a vírus alatt nagyobb prioritással bírókat. A harmadik és egyben utolsó rövidtávú megoldási javaslat a helyreállítás támogatása. A központi vállalatoknak kommunikálniuk kell minden érdekelt féllel, beleértve az ügyfeleket és a beszállítókat, és meg kell adniuk a szükséges támogatást a jogi segítségnyújtástól a pénzügyi segítségnyújtásig a müködésük helyreállításához [15].

A másik két javaslat a hosszú távú versenyképesség támogatója. Az első követelmény, hogy feltárjuk a globális ellátási lánc szük keresztmetszeteit, és valós időben tudjuk figyelemmel kísérni a kockázatot jelentő zavarokat. Az ellátási lánc sérülékenysége gyakran öt szegmensben fordul elő: tervezés és beszállítói hálózat, szállítás és logisztika, pénzügyi rugalmasság, termék komplexitás és szervezeti érettség [16]. Napjaink fejlett információs technológiái lehetővé teszik a jelentkező zavarok valós időben történő nyomon követését. Ezáltál már a hibák felmerülésének korai szakaszában lehetőség van a gyors beavatkozásra és eliminálásra egyaránt. A másik javaslat a hosszú távú versenyképesség megteremtéséhez a kiemelkedő stratégiai partnerekkel való együttmüködés létrehozása, egységes kockázatkezelési akciótervek kialakítása az anyag- és gyártási kapacitáshiány enyhítésére.

\subsection{Reakcióképesség fokozása zavarok esetén}

Kiszámíthatatlan időszakokban, mint ami napjainkat körülöleli a reakcióképesség kulcsfontosságú mozgatórugó a vállalatok életében, amely lehetővé teszi számukra, hogy gyors és költséghatékony válaszokat adjanak a kialakult zavarok kezelésére. A 3. ábra II. esete ad javaslatot rövid és hosszú távon a reakcióképesség fokozására. Rövid távon két módszert tudunk alkalmazni az alternatív beszerzést és a készlet redundanciát. A vírus által érintett területeken elhelyezkedő beszállítók helyett más alternatívát biztosító partnerek keresése megoldást jelenthet, illetve a készlet redundancia lehetóséget biztosít az ilyen esetekre fenntartott biztonsági erőforrások gyors allokálása.

Hosszú távon a reakcióképesség fokozására a készlet-redundancia mellett a beszállítók diverzifikálása csökkenheti a megszakítások kockázatát, amikor az ellátási láncok korlátozott tevékenységet tapasztalnak katasztrofális esemény miatt. Elönyös stratégia lehet a különböző földrajzi helyeken müködő szállítókkal való együttmüködés. Az ismertetett akciótervek bevezetésével viszont óvatosan kell, hogy bánjanak a vállalatok mert mind a láthatóság növelése, illetve a reakcióképesség fokozása költségkiadással jár, ami termékeik áremelkedéséhez vezethet gyengítve ezzel versenyképességüket a globális piacon. 


\section{Digitális ellátási láncok}

A COVID-19 terjedése rendkívüli késeseket okozott a nélkülözhetetlen cikkek szállításában, miközben a nem kritikus készletek hegyekben állnak, hiszen a kínálat nincs összhangban az aktuális kereslettel. Az ellátási lánc működésének javításához a beszállítói hálózatok vezetőinek tudniuk kell, hogy mi és hol történik, ideértve a COVID-19 jelentette jelenlegi és jövőbeli veszélyeket, az időjárást és a forgalmi viszonyokat. Az ellátási lánc optimalizálása évtizedek óta nagy prioritással bír. A költségek minimalizálása, a készletek csökkentése és az erőforrás kihasználás fokozása érdekében eltávolította a fizikai puffereket megteremtve a zavarok elnyelésére alkalmas rugalmasságot. A COVID-19 azt mutatja, hogy sok vállalat nincs teljesen tisztában az ellátási lánc kapcsolatai kiszolgáltatottságával a globális válságokkal szemben. Szerencsére új ellátási lánc technológiák jelennek meg, amelyek drámai módon javítják a láthatóságot a végpontok közötti ellátási láncban, és támogatják a vállalatok felkészülését az ilyen sokkok ellen. A hagyományos lineáris ellátási lánc modell (4. ábra) átalakul digitális ellátási hálózatokká (DSN) (5. ábra), ahol a funkcionális tárolók lebontásra kerülnek, és a szervezetek összekapcsolódnak teljes ellátási hálózatukkal a végpontok közötti láthatóság, az együttmüködés, az agilitás és az optimalizálás érdekében [17].

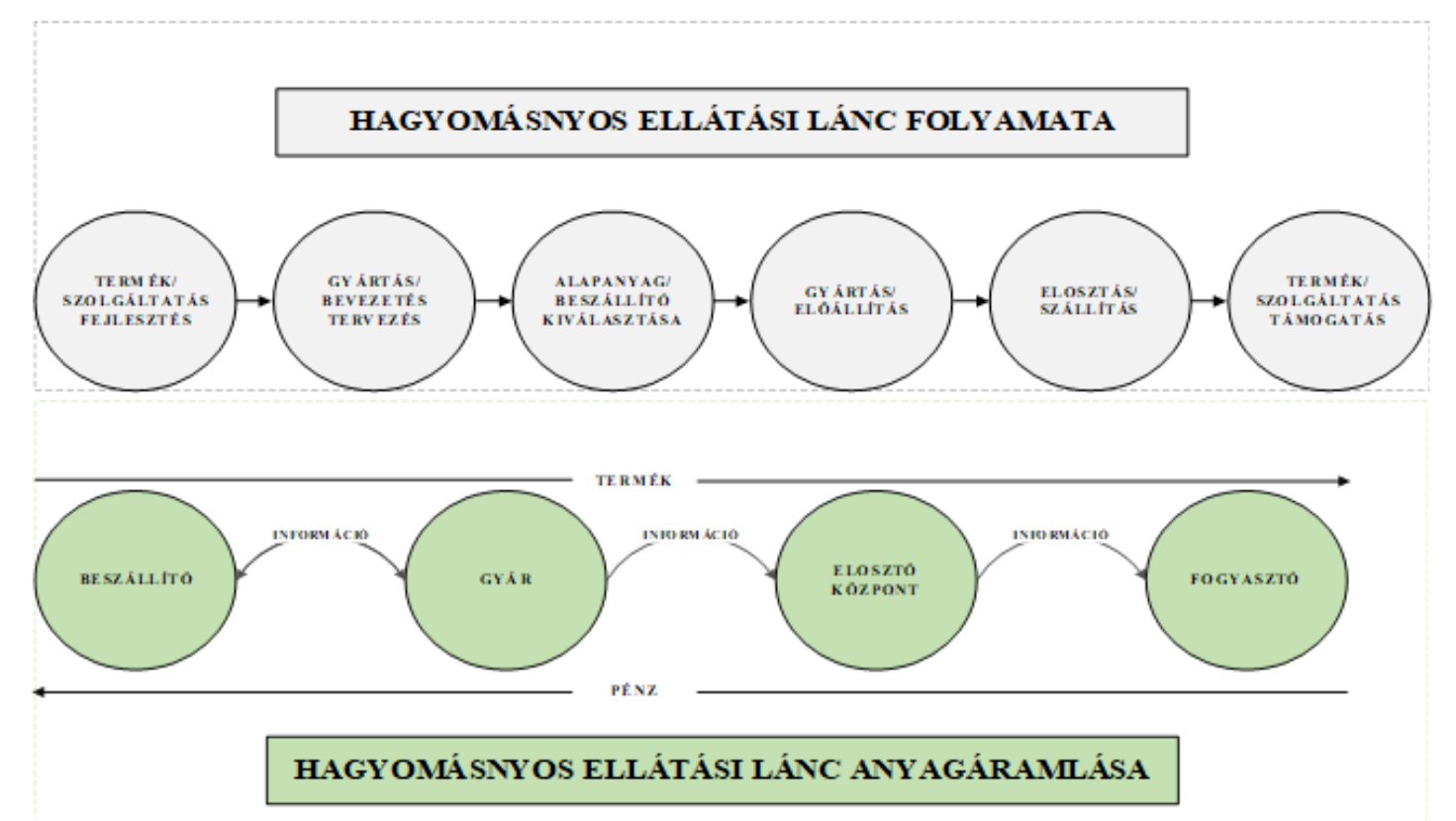

4. ábra Hagyományos ellátási lánc modell [18]

Az Ipar 4.0 lehetővé teszi az ellátási láncok digitális átalakulását olyan fejlett technológiákat kihasználva, mint a dolgok internete, a mesterséges intelligencia, a robotika és az $5 \mathrm{G}$ a digitális ellátási hálózatokat a jövő kihívásainak előrejelzésére és megválaszolására tervezték. Legyen szó „fekete hattyư" eseményről, mint például a COVID-19, kereskedelmi háborúról, háborús vagy terrorista cselekményröl, szabályozási változásról, munkaügyi vitáról, a kereslet hirtelen megugrásáról vagy beszállítói csődről, a DSN-t alkalmazó szervezetek készek lesznek megbirkózni a váratlan eseményekkel [19]. 


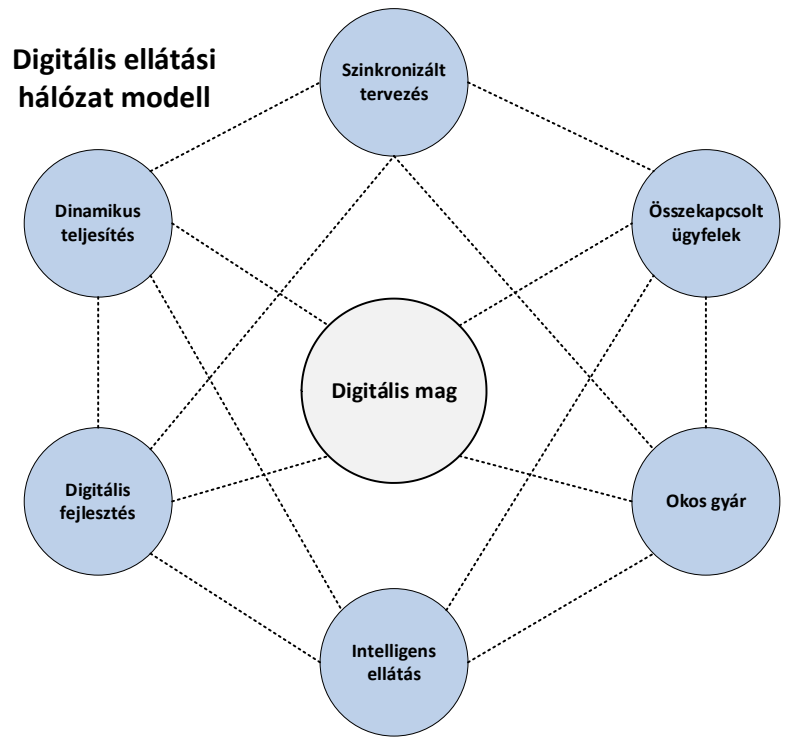

5. ábra Digitális ellátási hálózat modell [19]

A DSN hálózat képességeinek jellemzői (5. ábra) [19;20]:

- Digitális fejlesztés Ez a képesség felhasználja a technológiát a termékek koncepcionálásához, tervezéséhez és a termelésbe illesztéséhez, biztosítva a többfunkciós együttmüködést a termék életciklusán keresztül, és javítva a tervezés hatékonyságát olyan kiváló minőségü termékek kifejlesztése érdekében, amelyek kielégítik az egyedi vásárlói igényeket.

- Szinkronizált tervezés: Ez a képesség összehangolja a stratégiai-üzleti célokat a pénzügyi célokkal és az különbözö üzleti funkciók operatív terveivel. Ez az elrendezés segít hatékonyan kiszámítani az ügyfelek igényeit és optimalizálni a készletet a teljes DSN-ben.

- Intelligens ellátás: Ez a képesség segíti a vállalatokat abban, hogy hatékonyabban együtt müködjenek a stratégiai partnereikkel, és javítsák az ügyfelek és a szállítók elégedettségét azáltal, hogy fejlett elektronikus platformokat alkalmaznak a rendelésekhez és a számlázáshoz.

- Intelligens gyár: Ez a képesség az emberi és a gépi intelligencia számított egyensúlyát használja fel az üzleti teljesítmény és a munkavállalók biztonságának javítására a termelési és a keresleti adatok alapján.

- Dinamikus teljesítés: Ez az összekapcsolt, több vállalatot átfogó képesség a megfelelő terméket a megfelelő vevőhöz szállítja a megfelelő időben, növelve ezzel az általános vásárlói élményt. Olyan technológiákat alkalmaz, mint az IoT és a robotika, hogy valós idejü láthatóságot és rugalmasságot biztosítson az ellátási lánc egészében, elősegítve a többfunkciós együttmüködést és javítva a reakciókészséget.

- Összekapcsolt ügyfél: Ez a képesség lehetővé teszi a vállalatok számára, hogy a hagyományos ügyletalapú kapcsolattól a zökkenőmentes ügyfélelkötelezettség felé haladjanak az ügyfél életciklusa alatt. 


\section{7. Összefoglalás}

Lehetetlen előre megjósolni a világot globálisan érintő válságok bekövetkeztét, mint például a COVID19 kitörését. A vállalatok azonban robusztus és rugalmas ellátási lánc folyamatok és készenléti tervek kidolgozásával mérsékelhetik veszteségüket. A vészhelyzetekre való felkészülés és a reagálás hatékonysága nagymértékben függ a COVID-19 globális ellátási láncokra gyakorolt hatásának mély és átfogó megértésétől. Kijelenthető, hogy a COVID-19 három egyedi tulajdonságban tér el az eddigi járványoktól, a hosszabb időtartam, a globális kiterjedtség és a nagy mértékủ gazdasági hatás. A tanulmányban a logisztikai folyamatokra nehezedő problémák bemutatása lett összefoglalva. A bemutatott akciótervekkel lehetőség kínálkozik a globális ellátási láncban bekövetkezett zavarok hatékony elhárítására rövid és hosszútávon egyaránt. Ez a járvány arra kényszeríti a cégeket, hogy átértékeljék globális ellátási láncukat, és megszakítás esetén hatékonyan és agilisan cselekedjenek. A fejlett technológiai megoldások kínálta lehetőségek garanciát biztosítanak a globális ellátási láncoknak, hogy a reakcióképességük és átláthatóságuk hatékonyságát nagy mértékben fejlesszék.

\section{Köszönetnyilvánítás}

Az ismertetett tanulmány az EFOP-3.6.1-16-00011 "A fiatalabb és megújuló egyetem - Innovatív Tudás Város - Intézményfejlesztés a Miskolci Egyetem intelligens specializációra irányuló" Széchenyi 2020 program projektjének keretében valósult meg. E projekt megvalósítását az Európai Unió támogatja, az Európai Szociális Alap társfinanszírozásával.

\section{Irodalom}

[1] World Health Organization: WHO Coronavirus Disease (COVID-19) Dashboard. August 17, 2020.

[2] J. K. Jackson, M. A. Weiss, A. B. Schwarzenberg, and R. M. Nelson: Global economic effects of COVID-19. Congressional Research Service, Washington, DC, USA, April 10, 2020.

[3] World Trade Organization (WTO): Trade set to plunge as COVID-19 pandemic upends global economy. PRESS/855PRESS RELEASE 8 APRIL 2020

[4] M. Leonard: What procurement managers should expect from a bullwhip on crack. Supply Chain Dive March 26, 2020.

[5] Y. Ouyang: The effect of information sharing on supply chain stability and the bullwhip effect. European Journal of Operational Research 2007, 182(3):1107-1121. https://doi.org/10.1016/j.ejor.2006.09.037

[6] N. Donthu, A. Gustafsson: Effects of COVID-19 on business and research. Journal of Business Research 2020, 117:284-289. https://doi.org/10.1016/j.jbusres.2020.06.008

[7] Z. Xu, A. Elomri, L. Kerbache and A. El Omri: Impacts of COVID-19 on Global Supply Chains: Facts and Perspectives. IEEE Engineering Management Review 2020, 48(3):153-166. https://doi.org/10.1109/EMR.2020.3018420

[8] I. Twinn, N. Qureshi, M. L. Conde, C. G. Guinea, D. P. Rojas, J. Luo, H. Gupta: The Impact of COVID-19 on Logistics. International Finance Corporation (IFC) June 2020

[9] S. Dowsett and J. Lee: Coronavirus turmoil spreads to airline cargo operations. Reuters, London, U.K., February 5, 2020.

[10] A. Bombelli, B. F. Santos, and L. Tavasszy: Analysis of the air cargo transport network using a complex network theory perspective. Transportation Research Part E: Logistics and Transportation Review 2020, 138:101959. https://doi.org/10.1016/j.tre.2020.101959 
[11] J. S. Hofstetter: Extending management upstream in supply chains beyond direct suppliers. IEEE Engineering Management Review 2018, 46(1):106-116. https://doi.org/10.1109/EMR.2018.2810078

[12] Y. Ju, Y. Wang, Y. Cheng, J. Jia: Investigating the Impact Factors of the Logistics Service Supply Chain for Sustainable Performance: Focused on Integrators. Sustainability 2018, 11(2):538. https://doi.org/10.3390/su11020538

[13] S. Kumar and R. Anbanandam: Impact of risk management culture on supply chain resilience: An empirical study from Indian manufacturing industry. Proceedings of the Institution of Mechanical Engineers, Part O: Journal of Risk and Reliability 2020, 234:246-259. https://doi.org/10.1177/1748006X19886718

[14] P. Centobelli, R. Cerchione, and M. Ertz: Managing supply chain resilience to pursue business and environmental strategies. Business Strategy and the Environment 2020, 29:1215-1246. https://doi.org/10.1002/bse.2428

[15] B. McKenzie: Beyond COVID-19: Supply chain resilience holds key to recovery. April, 2020

[16] K. Alicke, X. Azcue, and E. Barriball: Supply-chain recovery in coronavirus times-plan for now and the future. Available: https://www. mckinsey.com/business-functions/operations/ourinsights/supply-chainrecovery-in-coronavirus-times-plan-for-now-and-the-future

[17] M. M. Queiroz, S. C. F. Pereira, R. Telles, M. C. Machado: Industry 4.0 and digital supply chain capabilities: A framework for understanding digitalisation challenges and opportunities. Benchmarking: An International Journal Available: https://www.emerald.com/insight/content/doi/10.1108/BIJ-12-2018-0435/full/html. https://doi.org/10.1108/BIJ-12-2018-0435

[18] E. Bernardes, R. Calderon, T. Wuest: Digital Supply Networks: Transform Your Supply Chain and Gain Competitive Advantage with Disruptive Technology and Reimagined Processes. ISBN13: 978-1260458190; ISBN-10: 1260458199

[19] E. Bernardes, A. Sinha, R. Calderon, T. Wuest: Digital Supply Networks transform the Future. ISE Magazine 2020, 52(5):28-33.

[20] A. Sinha, E. Bernardes, R. Calderon, T. Wuest: Digital Supply Networks: Transform Your Supply Chain and Gain Competitive Advantage with Disruptive Technology and Reimagined Processes. ISBN-13: 978-1260458190; ISBN-10: 1260458199 